\title{
EFFECTS OF CONNECTIVITY \\ ON THE FOREST BIRD COMMUNITIES OF ADJACENT FRAGMENTED LANDSCAPES
}

\author{
EFECTOS DE LA CONECTIVIDAD \\ SOBRE COMUNIDADES DE AVES FORESTALES \\ DE PAISAJES FRAGMENTADOS ADYACENTES
}

\author{
Edson VARGa LoPEs ${ }^{1 *}$, Luciana BAZA MendonÇA ${ }^{1}$, \\ Marcelo Augusto dOS SANTOS JUNIOR ${ }^{2}$, Germán Manuel LóPEZ-IBORRA ${ }^{3}$ \\ and Luiz DOS ANJOs ${ }^{4}$
}

SUMMARY.- We assessed bird sensitivity to forest fragmentation in two adjacent landscapes in the Atlantic Forest of southern Brazil. One landscape is naturally fragmented and has high connectivity, whereas the other is human-fragmented and has low connectivity. We tested whether the sensitivity of bird species to fragmentation depends more on the intrinsic characteristics of the birds than on landscape connectivity. Point counts were used to sample small and large forest remnants in each landscape. The abundance of each species in these remnants was used as a proxy for sensitivity. To test whether the two landscapes differ in connectivity, we compared the following landscape metrics: landscape shape index (LSI), proximity index (PROX) and connectance index (CONNECT). We analysed the sensitivity of 85 species, 51 of which occurred exclusively in one of the two landscapes. In the landscape with low connectivity we recorded a large number of sensitive species. Among the 34 species that occurred in both landscapes, 24 species (18 non-sensitive and six sensitive) had the same sensitivity. Landscape connectivity seems to be more significant when we focus on the bird communities as a whole. However, when we focus on the same bird species in different landscapes, intrinsic characteristics of species seem to affect their sensitivity to fragmentation more than does landscape connectivity, especially for bird species with lower sensitivity. Therefore, our results show that increasing landscape connectivity

1 Programa de Pós-Graduação em Ecologia de Ambientes Aquáticos Continentais-PEA, Universidade Estadual de Maringá. Av. Colombo, 5790, Bloco G90, CEP 87.020-900, Maringá, Paraná, Brasil.

2 Instituto Nacional de Pesquisas da Amazônia-INPA, Coordenação de Pesquisas em Dinâmica Ambiental-CDAM, Instituto Nacional de Ciência e Tecnologia dos Serviços Ambientais da Amazônia-INCT SERVAMB. Av. André Araújo 2936, Campus III, Manaus, Amazonas, Brasil.

3 Departamento de Ecología/IMEM Ramon Margalef, Universidad de Alicante, Apartado 99, 03080, Alicante, Spain.

4 Departamento de Biologia Animal e Vegetal, Universidade Estadual de Londrina, Caixa Postal 6001, CEP 86051-970, Londrina, Paraná, Brasil.

* Corresponding author: papaformiga@yahoo.com.br 
may not be the best tool for bird conservation in naturally fragmented landscapes. Nevertheless, it will be important to test further whether forest bird species are more sensitive to environmental degradation in naturally fragmented landscapes than in human-fragmented landscapes.

Key words: bird sensitivity, Brazilian Atlantic forest, forest fragmentation, habitat degradation, landscape connectivity.

RESUMEN.-En el presente estudio analizamos la sensibilidad de las aves a la fragmentación del bosque en dos paisajes contiguos de la Mata Atlántica del sur de Brasil. Uno de los paisajes está fragmentado de manera natural y presenta alta conectividad, mientras que en el otro la fragmentación es de origen antrópico y tiene baja conectividad. Evaluamos si la sensibilidad de las especies a la fragmentación depende más de sus características intrínsecas que de la conectividad del paisaje. Usamos puntos de conteo para estimar la abundancia de aves en fragmentos grandes y pequeños en cada paisaje, como un indicador de su sensibilidad a la fragmentación. Para testar si los dos paisajes difieren en conectividad calculamos las siguientes métricas del paisaje: índice de forma del paisaje (LSE), índice de proximidad (PROX) e índice de conectividad (CONNECT). Evaluamos la sensibilidad de 85 especies, de las cuales 51 ocurrieron solamente en uno de los dos paisajes. En el paisaje con baja conectividad registramos un mayor número de especies sensibles. Entre las 34 especies detectadas en los dos paisajes, 24 (18 no sensibles y 6 sensibles) mostraron la misma sensibilidad. Cuando consideramos la comunidad de aves en su conjunto la conectividad del paisaje resulta más relevante, sin embargo, al analizar la misma especie en diferentes paisajes, las características intrínsecas de la especie parecen afectar más su sensibilidad a la fragmentación que la conectividad del paisaje, especialmente en el caso de aves con baja sensibilidad. Nuestros resultados muestran que aumentar la conectividad del paisaje puede no ser la mejor herramienta para la conservación de las aves en paisajes fragmentados de manera natural. No obstante, sería importante estudiar si las aves forestales son más sensibles a la degradación ambiental en paisajes fragmentados naturalmente que en los fragmentados por la actividad humana.

Palabras clave: bosque atlántico brasileño, conectividad del paisaje, degradación ambiental, fragmentación forestal, sensibilidad de las aves.

\section{INTRODUCTION}

Different degrees of sensitivity to forest fragmentation have been reported for several bird species in many tropical areas (e.g., Stouffer and Bierregaard, 1995; Ferraz et al., 2003; Uezu et al., 2005; Anjos, 2006; Lees and Peres, 2006, 2010). However, sensitivity to fragmentation may also vary among populations of the same species that inhabit different landscapes (Anjos, 2006; Faria et al., 2006, 2007). For example, birds on the edge of their geographical ranges or that are closely associated with a particular forest type tend to be more sensitive to fragmentation (Anjos et al., 2010a, 2011). In both cases, small neighbour populations may not provide enough immigrants to compensate for emigration and mortality in forest remnants (Anjos et al., 2010a). Also, the level of forest fragmentation, which influences directly the degree of connectivity between patches with respect to, for instance, their size, shape, isolation or presence of corridors, could influence the sensitivity of the same species from different populations. This situation is poorly documented but there are some examples from the Amazon (Antongiovanni and Metzger, 2005) and the Brazilian Atlantic forest (Martensen et al., 2008). Hence, connectivity may also result in different levels of sensitivity within a single bird species.

In fact, two classes of factors may affect bird sensitivity to forest fragmentation (Laurance et al., 2002). One is related to landscape features, such as relief, climate 
and local fragmentation processes. The other is related to intrinsic features of a given species, such as natural history and genetic variability. Interactions between these two categories of factors could result, for example, in differences in competition, predation and parasitism, which could lead to differences in community dynamics in each fragmented landscape (Feeley and Terborgh, 2008).

In the present study, we assessed the sensitivity of bird species to forest fragmentation in two adjacent landscapes separated from each other by a river. One landscape comprises poorly connected forest remnants and is a result of heavy deforestation of a continuous forest. The other landscape is naturally fragmented and contains forest remnants connected by riparian forests. Since these two landscapes are close to each other, and many species have populations on both riverbanks, we hypothesised that bird sensitivity to forest fragmentation is explained by differences in landscape connectivity and not by intrinsic features of species. We suggest that, if a given bird species present in both landscapes has different sensitivity to fragmentation in each landscape, sensitivity should be attributed to the landscape effect. If this is true, landscape structure has a stronger effect on bird sensitivity to fragmentation than intrinsic features of the species. Nevertheless, an opposite result, i.e. similar sensitivity in both landscapes, would indicate that the influence of intrinsic features of the species is stronger than those of the landscape structure. In addition, we evaluated differences in species richness and in forest edge tolerance, body size, forest stratum used and diet. These ecological features have frequently been associated with bird sensitivity to fragmentation (Leck, 1979; Restrepo et. al., 1997; Laurance and Vasconcelos, 2009). We therefore aimed to test which of these ecological characteristics of bird species remain constant, regardless of differences in landscape connectivity.

\section{MATERIALS AND METHODS}

\section{Study area}

The present study was carried out on the Upper Paraná River Floodplain $\left(22^{\circ} 32^{\prime} \mathrm{S}\right.$ to $22^{\circ} 59^{\prime} \mathrm{S}$ and $53^{\circ} 08^{\prime} \mathrm{W}$ to $53^{\circ} 4^{\prime} \mathrm{W}$; fig. 1 ), Southern Brazil. In this region, the Paraná River separates two Brazilian states: Paraná, on the eastern riverbank, and Mato Grosso do Sul, on the western riverbank. This region has an average annual temperature of $22{ }^{\circ} \mathrm{C}$, a maximum temperature of $26^{\circ} \mathrm{C}$ in summer, a minimum temperature of $18{ }^{\circ} \mathrm{C}$ in winter, and annual rainfall of 1,500 mm (Maack, 1981).

The vegetation on both riverbanks is seasonal semi-deciduous forest. However, the asymmetry between riverbanks contributes to create different landscapes. The eastern riverbank is $5-15 \mathrm{~m}$ high, which prevents floods. In contrast, the western riverbank is only a few centimetres high, which allows frequent floods and creates a large floodplain that reaches up to $20 \mathrm{~km}$ away from the Paraná River (Agostinho et al., 2002). The forest on the western riverbank comprises relatively well-preserved forest remnants, which are strongly interconnected and lie on elevated plateaus surrounded by naturally open wetlands (Campos and Souza, 1997). There are riparian forests along several streams and rivers, which increase the connectivity of forest remnants. Currently, most of the western riverbank is a reserve known as the Parque Estadual das Várzeas do Rio Ivinhema. A different situation is observed on the eastern riverbank, where a intensive deforestation led to the isolation of forest remnants. The matrix on the eastern riverbank is composed of disturbed habitats, mainly pastures and crops (Campos and Souza, 1997; see fig. 1). Thus, although fragmentation has occurred on both riverbanks, it has been more intense on the eastern riverbank.

We selected two landscapes of similar size $\left(865 \mathrm{~km}^{2}\right)$ on opposite riverbanks of the 


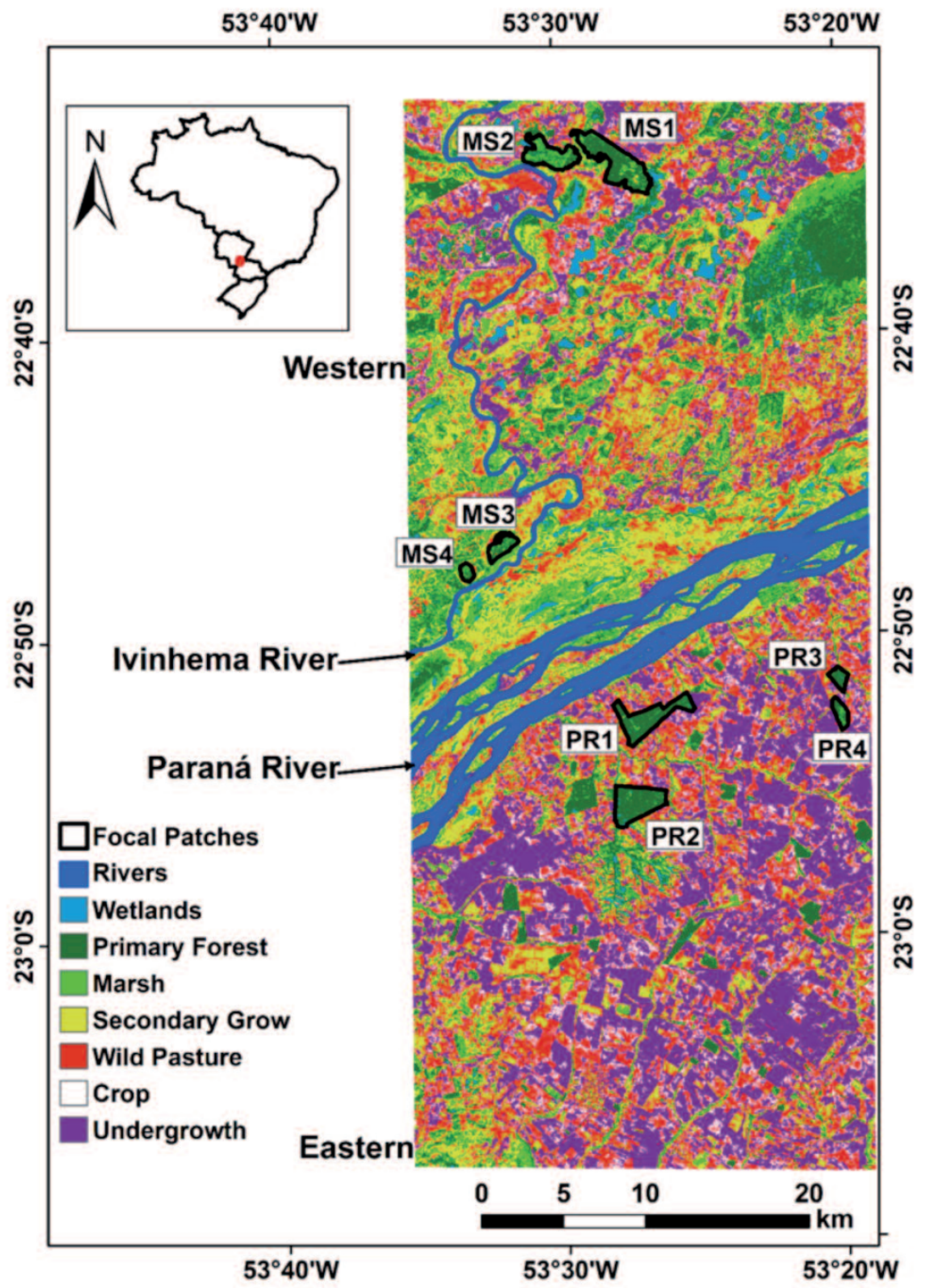

FIG. 1.-Classified image of LandSat 5 satellite of the Upper Paraná River Floodplain region showing the eight areas selected for this study; four forest remnants on the eastern riverbank of the Paraná River: PR1, PR2, PR3, and PR4, and four forest remnants on the western riverbank of the Paraná River: MS1, MS2, MS3, and MS4. The area, percentage cover and number of remnants within each category of soil cover are shown in table 1. See Methods for details of each class.

[Imagen clasificada de LandSat 5 de la llanura de inundación del curso alto del río Paraná, que muestra las ocho áreas seleccionadas para este estudio; cuatro bosques remanentes en el margen este del río Paraná: PR1, PR2, PR3, y PR4, y cuatro bosques remanentes en su margen oeste: MS1, MS2, MS3, y MS4. El área, porcentaje de cobertura y número de parches de cada categoría de cobertura del suelo se muestran en la tabla 1. Véase Métodos para los detalles de cada categoría.] 
Paraná River using a satellite image of the region (fig. 1). In these landscapes we selected four forest remnants on the humanfragmented eastern riverbank: PR1 (536 ha), PR2 (552 ha), PR3 (102 ha), and PR4 (115 ha), and four forest remnants on the naturally-fragmented western riverbank: MS1 (729 ha), MS2 (417 ha), MS3 (174 ha), and MS4 (72 ha).

\section{Fieldwork}

We assessed bird species abundance using 15-minute point counts (Blondel et al., 1970; Bibby et al., 1993). In each remnant, we established six points along a trail, at $200 \mathrm{~m}$ intervals and at least $50 \mathrm{~m}$ from the forest edge. We sampled for 2 h 45 minutes, starting about half an hour before sunrise, when diurnal bird activity begins. We sampled each point in each remnant six times, on different days between August and December 2006, a period that coincides with the breeding season of most bird species in the region (Piratelli et al., 2000; Marini and Durães, 2001). We obtained a total of 36 15-minute samples in each remnant (288 in total). We included all diurnal birds observed or heard within a 100-m radius, but excluded the families Accipitridade, Falconidae and Trochilidae, because they are poorly represented in pointcounts (Anjos et al., 2010b).

\section{Data analysis}

\section{Landscape metrics}

We used bands 3, 4 and 5 of a LandSat 5 satellite image with pixel spatial resolution of $30 \times 30 \mathrm{~m}$ from 2006 . The bands were combined into a single image and classified into eight classes based on hydrology and soil cover: (1) rivers, (2) wetlands, (3) primary forest, (4) marsh (including seasonally flooded forests), (5) secondary growth, (6) rough pasture (including pastures with little or no management with shrubby vegetation, locally known as pasto sujo), (7) crops and (8) undergrowth (including pastures under intensive grazing where the vegetation reaches a few centimetres in height, and areas of bare soil). The first two classes were excluded from the analyses. Four scenarios were prepared from classified images and they differ in terms of classes used in the analysis. Scenario 1: all classes of soil cover; Scenario 2: class 3 only; Scenario 3: classes 3 and 4 only; and Scenario 4: classes 3, 4, and 5 only. We used these scenarios in the analyses because they include the vegetation that is potentially used by forest birds.

For each class identified in each landscape we estimated the area $\left(\mathrm{km}^{2}\right)$, the percentage cover $(\%)$ and the number of patches (NP). NP was calculated by transforming the classified image into polygons and counting the polygons as patches. As a result, a patch could be a single pixel or groups of pixels, depending to the pixel value (according to land cover classes of classified image). The number of patches could vary from 1 , if all landscape pixels have the same value, to a limitless value, when pixels have different values. Thus, isolated pixels can be a patch and have an area of $30 \times 30 \mathrm{~m}\left(900 \mathrm{~m}^{2}\right)$, if one pixel of a given value is surrounded by pixels of different values.

We used the FRAGSTATS 4.2 program (McGarigal et al., 2012) for calculating landscape metrics: landscape shape index (LSI), proximity index (PROX) and connectance index (CONNECT). The LSI measures the perimeter-to-area ratio of the landscape and provides a standardised measure of total edge or edge density adjusted to the size of the landscape. It can be interpreted as a measure of the overall geometric complexity of the landscape; however, it can also be interpreted as a measure of landscape disaggregation. The PROX (Gustafson 
and Parker, 1992) considers the size and proximity of all patches whose edges are within a chosen radius from the focal patch. It increases as the surroundings (defined by this chosen radius) are progressively occupied by patches of the same type and as those patches become closer and more contiguous (or less fragmented). The PROX distinguishes sparse distributions of small habitat patches from clusters of large patches and is most suited to evaluate 'high contrast' landscapes, where the habitat of interest differs from the surrounding matrix. It is large when the patch is surrounded by larger and/or closer patches, and decreases as patches become smaller and/or sparser (Gustafson and Parker, 1994). CONNECT is defined as the number of functional connections between patches of the same class, where each pair of patches is either connected or not based on a user-specified distance criterion. CONNECT is a percentage of the maximum possible connectance given the number of patches. For calculating PROX and CONNECT we used four different distance classes within the chosen radius $(0.5 \mathrm{~km}, 1 \mathrm{~km}, 3 \mathrm{~km}$ and $5 \mathrm{~km})$.

\section{Sensitivity analysis}

Based on the data of Laurance (2010), Anjos et al. (2011) argued that in a fragmented landscape, forest remnants up to 300 ha could be considered small and, hence, that edge effects would strongly affect the persistence of forest birds that dwell in them. By contrast, forest remnants larger than 300 ha would have a core area that is relatively immune to edge effects, which increases species' persistence. Hence, we selected two large and two small remnants in each landscape: PR1, PR2, MS1 and MS2 are large and PR3, PR4, MS3 and MS4 are small. To assess bird sensitivity, we used a $\mathrm{G}$ test to compare the number of contacts of bird species in large versus small remnants, when the expected frequency was greater than five (Fowler and Cohen, 1986). Species unaffected or benefited by forest fragmentation (hereafter non-sensitive species) were those that had similar numbers of contacts in small and large remnants or that reached higher values in the former than in the latter. Species negatively affected by forest fragmentation (hereafter sensitive species) were those that occurred only in large remnants or that had a larger number of contacts in large than in small remnants.

We classified each bird species according to its preferred forest stratum, edge tolerance, body size and diet. Several studies have shown that these factors affect species' sensitivity to forest fragmentation (e.g., Willis, 1979; Stouffer and Bierregaard, 1995; Christiansen and Pitter, 1997; Ribon et al., 2003; Sodhi et al., 2004; Lees and Peres, 2006).

We used the database of Parker et al. (1996) to determine the preferred forest stratum (ground/mid-storey or sub-canopy/ canopy) and edge tolerance of each bird species. We classified the species according to body size (Dunning, 2008) as small/ medium birds (100 g or less) or large birds (over $100 \mathrm{~g}$ ). We also classified bird species according to diet into specialists (insectivores and frugivores) and generalists (omnivores). Dietary classification followed del Hoyo et al. (1992-2011).

We used a contingency Chi-squared test for independence to compare the number of bird species in large and small forest remnants between landscapes. The same test was employed to compare the number of sensitive and non-sensitive species between landscapes and the number of species in categories of forest strata, edge tolerance, body mass classes and diet classes. We applied the test when all expected frequencies were greater than five (Fowler and Cohen, 1986). In order to avoid the problem of inflated false-positive rates as a consequence of the large number of hypothesis 
tests, we adjusted $p$ values using the Benjamini and Hochberg (1995) False Discovery Rate (FDR) procedure, as implemented in the $\mathrm{R}$ function $\mathrm{p}$.adjust ( $\mathrm{R}$ Development Core Team, 2008).

\section{RESUlTS}

\section{Landscape metrics}

On the western riverbank, classes 3 (primary forest), 4 (marsh) and 5 (secondary growth) have larger areas, a larger percentage cover $(\%)$, and a larger number of patches than on the eastern riverbank. In contrast, the eastern riverbank has a larger area, larger percentage cover (\%) and larger number of patches for classes 6 (rough pasture), 7 (crops) and 8 (undergrowth; table 1).

The results of LSI, PROX, and CONNECT are presented in table 2 . In all scenarios, the LSI-value was higher in the landscape of the western riverbank than in the landscape of the eastern riverbank. The LSI-values suggest that on the western riverbank the patches of the analysed classes are more disaggregated than those of the eastern riverbank (more aggregated). The PROX-values (for all distance classes) in all scenarios were higher on the western than on the eastern riverbank. Based on the PROX-values, the

TABLE 1

Area, percentage cover (PC), and number of patches (NP) in the western and eastern riverbanks of the studied sector of the Upper Paraná River Floodplain region. See Methods for details of each soil cover class. Classes 1 and 2 were not used in analyses and are included here to show their representation on each riverbank.

[Área, porcentaje de cobertura (PC) y número de parches $(N P)$ en los márgenes este y oeste del sector estudiado en la llanura de inundación del curso alto del río Paraná. Véase Métodos para los detalles de cada clase de cobertura del suelo. Las clases 1 y 2 no se usaron en los análisis y se incluyen aquí para mostrar su extensión en cada margen.]

\begin{tabular}{|c|c|c|c|c|c|c|c|}
\hline \multirow[b]{2}{*}{ Classes } & \multirow[b]{2}{*}{ Total } & \multicolumn{2}{|c|}{ Area $\left(\mathbf{k m}^{2}\right)$} & \multicolumn{2}{|c|}{$\mathrm{PC}(\%)$} & \multicolumn{2}{|c|}{ NP } \\
\hline & & Western & Eastern & Western & Eastern & Western & Eastern \\
\hline 1 and 2 (rivers and wetlands) & 57.5 & 49.2 & 8.3 & 5.7 & 1 & - & - \\
\hline 3 (Primary forest) & 174.7 & 125.7 & 49.0 & 14.5 & 5.7 & 12,166 & 4198 \\
\hline 4 (Marsh) & 180.4 & 135.6 & 44.8 & 15.7 & 5.2 & 23,880 & 11,071 \\
\hline 5 (Secondary growth) & 390.2 & 251.2 & 139.0 & 29.1 & 16.1 & 18,849 & 14,793 \\
\hline 6 (Rough pasture) & 351.0 & 153.8 & 197.3 & 17.8 & 22.8 & 19,891 & 22,057 \\
\hline 7 (Crops) & 179.3 & 57.9 & 121.5 & 6.7 & 14.0 & 19,020 & 31,376 \\
\hline 8 (Undergrowth) & 396.2 & 91.3 & 304.9 & 10.5 & 35.2 & 5424 & 7932 \\
\hline Total & 1729.3 & 864.7 & 864.8 & 100.0 & 100.0 & 99,230 & 91,427 \\
\hline
\end{tabular}


TABLE 2

Landscape metrics for the four scenarios on the two riverbanks of the Paraná River. SR: Search radius varies from $0.5 \mathrm{~km}$ to $5 \mathrm{~km}$. LSI: Landscape Shape Index, PROXMN: average of the Proximity Index, PROXSD: Standard Deviation of the Proximity Index, PROXCV: Coefficient of Variation of the Proximity Index, CONNECT: Connectance Index.

\begin{tabular}{|c|c|c|c|c|c|c|}
\hline Riverbank & SR & LSI & PROXMN & PROXSD & PROXCV & CONNECT \\
\hline \multicolumn{7}{|l|}{ Scenario 1} \\
\hline Western & \multirow{2}{*}{$0.5 \mathrm{~km}$} & 175 & 193 & 1081 & 560 & 0.18 \\
\hline Eastern & & 150 & 110 & 521 & 474 & 0.15 \\
\hline Western & \multirow{2}{*}{$1 \mathrm{~km}$} & 175 & 195 & 1081 & 554 & 0.55 \\
\hline Eastern & & 150 & 112 & 521 & 467 & 0.47 \\
\hline Western & \multirow{2}{*}{$3 \mathrm{~km}$} & 175 & 197 & 1081 & 549 & 3.66 \\
\hline Eastern & & 150 & 113 & 522 & 461 & 3.25 \\
\hline Western & \multirow{2}{*}{$5 \mathrm{~km}$} & 175 & 197 & 1081 & 548 & 8.89 \\
\hline Eastern & & 150 & 114 & 522 & 459 & 8.10 \\
\hline \multicolumn{7}{|l|}{ Scenario 2} \\
\hline Western & \multirow{2}{*}{$0.5 \mathrm{~km}$} & 115 & 223 & 1203 & 541 & 0.19 \\
\hline Eastern & & 58 & 31 & 131 & 423 & 0.29 \\
\hline Western & \multirow{2}{*}{$1 \mathrm{~km}$} & 115 & 225 & 1203 & 536 & 0.55 \\
\hline Eastern & & 58 & 32 & 132 & 412 & 0.76 \\
\hline Western & \multirow{2}{*}{$3 \mathrm{~km}$} & 115 & 226 & 1203 & 532 & 3.58 \\
\hline Eastern & & 58 & 33 & 132 & 404 & 3.76 \\
\hline Western & \multirow{2}{*}{$5 \mathrm{~km}$} & 115 & 226 & 1203 & 531 & 8.64 \\
\hline Eastern & & 58 & 33 & 132 & 402 & 8.61 \\
\hline
\end{tabular}

landscape of the western riverbank has patches that are closer to each other and more contiguous, i.e. it is less fragmented than the landscape of the eastern riverbank. The CONNECT-value for Scenario 1, in all distance classes analysed, was higher for the landscape of the western riverbank than for the landscape of the eastern riverbank. However, in Scenario 2, for distance classes from $0.5 \mathrm{~km}$ to $3 \mathrm{~km}$, the CONNECT-value was lower on the western than on the eastern riverbank; for the distance class of $5 \mathrm{~km}$ the pattern was similar to that observed in Scenario 1. In Scenario 3, all CONNECTvalues were lower on the western than on the eastern riverbank. Finally, in Scenario 4, for the distance class of $0.5 \mathrm{~km}$ the CONNECTvalue was higher on the western riverbank and for the other distance classes it was higher on the eastern riverbank (table 2). 
TABLE 2 (cont.)

[Métricas del paisaje para los cuatro escenarios en ambas márgenes del río Paraná. SR: radio de búsqueda, que varía entre 0,5 km y $5 \mathrm{~km}$. LSI: Índice de forma del paisaje, PROXMN: media del índice de proximidad, PROXSD: Desviación típica del índice de proximidad, PROXCV: Coeficiente de variación del índice de proximidad, CONNECT: índice de conectividad.]

\begin{tabular}{|c|c|c|c|c|c|c|}
\hline Riverbank & SR & LSI & PROXMN & PROXSD & PROXCV & CONNECT \\
\hline \multicolumn{7}{|l|}{ Scenario 3} \\
\hline Western & \multirow{2}{*}{$0.5 \mathrm{~km}$} & 154 & 108 & 735 & 681 & 0.16 \\
\hline Eastern & & 95 & 16 & 76 & 476 & 0.22 \\
\hline Western & \multirow{2}{*}{$1 \mathrm{~km}$} & 154 & 109 & 735 & 672 & 0.50 \\
\hline Eastern & & 95 & 16 & 76 & 462 & 0.61 \\
\hline Western & \multirow{2}{*}{$3 \mathrm{~km}$} & 154 & 111 & 735 & 663 & 3.33 \\
\hline Eastern & & 95 & 17 & 76 & 449 & 3.70 \\
\hline Western & \multirow{2}{*}{$5 \mathrm{~km}$} & 154 & 111 & 735 & 660 & 8.16 \\
\hline Eastern & & 95 & 17 & 76 & 445 & 8.74 \\
\hline \multicolumn{7}{|l|}{ Scenario 4} \\
\hline Western & \multirow{2}{*}{$0.5 \mathrm{~km}$} & 165 & 319 & 1455 & 456 & 0.51 \\
\hline Eastern & & 130 & 44 & 171 & 389 & 0.19 \\
\hline Western & \multirow{2}{*}{$1 \mathrm{~km}$} & 165 & 322 & 1455 & 451 & 0.51 \\
\hline Eastern & & 130 & 45 & 171 & 381 & 0.56 \\
\hline Western & \multirow{2}{*}{$3 \mathrm{~km}$} & 165 & 325 & 1455 & 448 & 3.38 \\
\hline Eastern & & 130 & 46 & 171 & 373 & 3.50 \\
\hline Western & \multirow{2}{*}{$5 \mathrm{~km}$} & 165 & 325 & 1455 & 447 & 8.27 \\
\hline Eastern & & 130 & 46 & 171 & 371 & 8.40 \\
\hline
\end{tabular}

\section{Bird species sensitivity}

We recorded a total of 94 bird species during our study (69 on the eastern riverbank and 78 on the western riverbank; Appendix). We found 69 bird species in small forest remnants and 54 in large forest remnants on the western riverbank. On the eastern riverbank, we found 45 bird species in small remnants and 63 in large remnants. The proportion of species in small and large forest remnants differed between the western and eastern riverbanks $\left(\chi^{2}=4.8\right.$, d.f. $\left.=1, P=0.03\right)$.

Eighty-five bird species had sufficient contacts to assess their sensitivity to forest fragmentation. On the eastern riverbank, 29 species were sensitive to forest fragmentation and 26 species were not, whereas on the western riverbank 17 species were sensitive and 47 species were not. The propor- 
tion of sensitive/non-sensitive species differed between riverbanks $\left(\chi^{2}=8.5\right.$, d.f. $=1$, $P=0.003$ ).

Among those 85 bird species 34 occurred in both landscapes. Among these, 24 species (six sensitive and 18 non-sensitive) showed the same sensitivity to fragmentation in both landscapes. Ten species showed different sensitivity in the two landscapes: the bluefronted parrot Amazona aestiva, eared pygmy-tyrant Myiornis auricularis and squirrel cuckoo Piaya cayana were classified as non-sensitive on the eastern riverbank but were classified as sensitive on the western riverbank. The yellow tyrannulet Capsiempis flaveola, golden-crowned warbler Basileuterus culicivorus, tataupa tinamou Crypturelus tataupa, plush-crested jay Cyanocorax chrysops, ruddy quail-dove Geotrygon montana, tropical parula Parula

TABLE 3

Number of sensitive and non-sensitive bird species on the eastern and western riverbanks. Species were grouped according to: forest edge tolerance, body size, preferred forest stratum and diet (generalist; omnivores and specialist; insectivores plus frugivores). The last column presents the $p$ values of contingency Chi-squared tests for independence adjusted using the Benjamini and Hochberg (1995) False Discovery Rate (FDR) procedure.

[Número de especies sensibles y no sensibles en cada margen del río. Las especies se han agrupado en función de su tolerancia al borde del bosque, tamaño corporal, estrato vertical preferido y dieta (los generalistas incluyen los omnívoros y los especialistas los insectívoros más los frugívoros). La última columna muestra el nivel de significación, $p$, de tests de Chi ${ }^{2}$ que comparan el número de especies sensibles y no sensibles incluidas en cada categoría entre márgenes del río, ajustados utilizando la tasa de descubrimientos falsos (FDR) de Benjamini and Hochberg (1995).]

\begin{tabular}{|c|c|c|c|c|c|}
\hline \multirow[b]{2}{*}{ Categories } & \multicolumn{2}{|c|}{ Eastern riverbank } & \multicolumn{2}{|c|}{ Western riverbank } & \multirow{2}{*}{$\begin{array}{c}\text { FDR adjusted } \\
p \text {-value }\end{array}$} \\
\hline & Sensitive & Non-sensitive & Sensitive & Non-sensitive & \\
\hline \multicolumn{6}{|l|}{ Edge tolerance } \\
\hline Yes & 7 & 15 & 3 & 23 & 0.1 \\
\hline No & 22 & 11 & 14 & 24 & 0.04 \\
\hline \multicolumn{6}{|l|}{ Body size } \\
\hline Small/medium & 20 & 22 & 12 & 37 & 0.04 \\
\hline Large & 9 & 4 & 5 & 10 & 0.08 \\
\hline \multicolumn{6}{|l|}{ Stratum } \\
\hline Ground/mid-storey & 11 & 9 & 5 & 18 & 0.04 \\
\hline Sub-canopy/canopy & 18 & 17 & 12 & 29 & 0.08 \\
\hline \multicolumn{6}{|l|}{ Diet } \\
\hline Generalist & 13 & 15 & 3 & 27 & 0.008 \\
\hline Specialist & 16 & 11 & 14 & 20 & 0.1 \\
\hline
\end{tabular}


pitiayumi and chestnut-eared aracari Pteroglossus castanotis were classified as sensitive on the eastern riverbank, but as non-sensitive on the western riverbank (Appendix).

Some functional groups show different sensitivity to fragmentation between landscapes (table 3). Among species that avoid forest edges there is a trend for a larger proportion of sensitive species on the eastern riverbank. In contrast, among ground/midstorey stratum birds, small/medium size birds, and omnivorous birds, we found a larger proportion of non-sensitive species on the western riverbank (table 3).

\section{DISCUSSION}

The indicators used in the quantitative analysis of the landscape strongly suggest a difference in connectivity for forest birds between the landscapes of the two riverbanks. However, the CONNECT-values, contrary to what was expected, were smaller on the western river bank for all distance classes of scenarios 2, 3 and 4, except the $5 \mathrm{~km}$ and $0,5 \mathrm{~km}$ distance classes of scenarios 2 and 4, respectively. The CONNECTvalue of the naturally fragmented western riverbank, was predominantly smaller than that of the human-fragmented eastern riverbank, probably because the landscape patches of the eastern riverbank are more aggregated and less dispersed than the landscape patches of the western riverbank (according to the results of the LSI). Hence, from the perspective of a forest bird, the landscape of the western riverbank is more amenable to dispersal or foraging movements. This is also suggested for the spatial distribution of the classes 3, 4, and 5 on the western riverbank. These classes represent the vegetation that is more used by forest birds. On the western riverbank there are more, and more widely distributed, patches of these classes than in the landscape of the eastern riverbank. This may contribute to the maintenance of the forest bird community on this riverbank compared to the eastern riverbank, where the matrix is dominated by areas of low vegetation and crops, mainly classes 7 and 8 .

Fifty-one bird species were found in just one of the landscapes. This could be because of the forest fragmentation that has already occurred in the region and which could have eliminated some bird species on either riverbank, especially on the eastern riverbank, where fragmentation processes were more intense. Another possible cause for the relatively great number of bird species found in only one landscape is that this region is a transition zone between two large Brazilian biomes (Atlantic Forest and Cerrado; Campos and Souza, 1997). Over $60 \%$ of bird species in the study area are associated with both of these biomes (Parker et. al., 1996). Some species are biogeographically associated with only one of these biomes. They include the rufous-capped motmot Baryphthengus ruficapillus, recorded only in eastern riverbank, and the blue-crowned motmot Momotus momota recorded only in the western riverbank, the first associated with Atlantic forest and the later with Cerrado (Parker et. al., 1996). Among the 34 bird species found in both landscapes, $24(71 \%)$ had the same sensitivity to forest fragmentation. Therefore, our data suggest that intrinsic features of these bird species have a stronger effect on their distribution than landscape features.

Among the ten species that had different sensitivity, seven were sensitive on the eastern riverbank (low connectivity) and non-sensitive on the western riverbank (high connectivity). Hence, these species seem to have lower sensitivity only where landscape connectivity is higher. The remaining three species (blue-fronted parrot, eared pygmytyrant, and squirrel cuckoo) are more diffi- 
cult to evaluate because they showed an opposite trend: they were non-sensitive on the eastern riverbank but sensitive on the western riverbank. It is possible that some habitat attributes, which are particularly important to those species, differed between landscapes. Moreover, functional connectivity is probably not the same for all species. Hence, perhaps for some bird species the functional connectivity of the landscape could be greater on the eastern riverbank. Such information is difficult to detect with the landscape metrics used in the present study because they only measure the structural connectivity of the landscape.

It is important to highlight that all 18 bird species that were non-sensitive on both riverbanks were previously classified as lowsensitivity by Ribon et al. (2003) and Anjos (2006). This suggests that non-sensitive bird species remain non-sensitive everywhere. In contrast, sensitive species may respond differently to forest fragmentation and may become sometimes non-sensitive. It is possible that for these species such factors as habitat matrix, presence of microhabitats or of competitors/predators could have a stronger effect. So, if their responses to such factors evolve differently in distinct landscapes, such species may vary in how they are affected by forest fragmentation. Our results show that when we focus on the bird communities as a whole, landscape connectivity seems to be more significant. However, when we focus on the same bird species in different landscapes, intrinsic species characteristics seem to affect their sensitivity to fragmentation more than landscape connectivity does.

We suggest that the high connectivity of the studied landscape on the western riverbank may explain the unexpected result of small forest remnants having a larger number of species than large remnants. In a naturally fragmented landscape with high connectivity, many species could frequently move between forest remnants in search of better environmental conditions or temporarily resource-rich areas. In regions under regular flooding, such as the western riverbank, the quality of each forest remnant may frequently change. Therefore, in such a dynamic system bird species are probably more limited by habitat quality than habitat size. On the eastern riverbank, where there is no flooding and landscape connectivity is low, bird communities would tend to be more strongly limited by habitat size.

Several studies have indicated the importance of landscape connectivity for forest birds both in naturally-fragmented (Anjos and Boçon, 1999; Andrade and Marini, 2001; Yabe and Marques, 2001) and human-fragmented areas (Stouffer and Bierregaard, 1995; Gascon et al., 1999; Antongiovanni and Metzger, 2005; Uezu et al., 2005; Stouffer et al., 2006; Martensen et al., 2008; Uezu et al., 2008). A previous study, also carried out in the state of Paraná, showed that naturally fragmented landscapes do not necessarily have higher connectivity (Anjos, 2004). This study shows that, in comparison to a humanfragmented landscape, the bird community in a naturally fragmented landscape is not strongly influenced by connectivity.

Indeed, we show that landscape connectivity may not necessarily be the most important conservation criterion in a naturally fragmented landscape. In our study system the quality of forest remnants on western riverbank seems unstable due to flooding, the intensity of which varies between years. Therefore, we highlight here the importance of knowing the features of a given landscape to predict species richness. This is particularly important in megadiverse regions such as the Neotropics, where many factors (historical, ecological and anthropogenic) act simultaneously to generate distinct bird communities both in naturally-fragmented and human-fragmented landscapes. 
Acknowledgements. - Nupélia (Núcleo de Pesquisa em Liminologia, Ictiologia e Aquicultura) and PEA (Programa de Pós-Graduação em Ecologia de Ambientes Aquáticos Continentais) of Universidade Estadual de Maringá, through PELD (Long Term Ecological Research Program), provided us with logistic support and infrastructure. The CNPq (Brazilian Research Council) gave us financial support through the Mata Atlântica Program. E. V. Lopes received a $\mathrm{PhD}$ scholarship from $\mathrm{CNPq}$ during the present study and a sandwich scholarship for a four-month research stay at the Universidad de Alicante in Spain (processes 140353/2006-2 and 202232/2007-7, respective1y). L. B. Mendonça received a $\mathrm{PhD}$ scholarship from CNPq (process 140317/2006-6). L. dos Anjos received a CNPq research productivity fellowship level 1D (process 305593-2007-2). Secretaria de Meio Ambiente of Mato Grosso do Sul gave permission for fieldwork in the Parque Estadual das Várzeas do Rio Ivinhema. We thank the land owners that granted us access to forest remnants located in their properties. We are also grateful to Alex Jahn and an anonymous reviewer who made important contributions to the manuscript.

\section{BIBLIOGRAPHY}

Agostinho, A. A, Thomaz, S. M. and NaKatani, K. 2002. A planície de inundação do alto rio Paraná: site 6. In, Seeliger, U., Cordazzo, C. and Barbosa, F. (Eds): PELD: os sites e o programa brasileiro de pesquisas ecológicas de longa duração, pp. 101-124. FURG/UFMG, Belo Horizonte, Brasil.

Andrade, R. D. and Marini, M. Â. 2001. Movement of birds in natural forest patches in Southeast Brazil. In, Albuquerque, J. L. B., Cândido Jr., J. F. and Straube, F. C. (Eds): Ornitologia e conservação: da ciência às estratégias, pp. 125-136. Editora UNISUL, Tubarão, Santa Catarina, Brasil.

ANJOS, L. DOS. 2004. Species richness and relative abundance of birds in natural and anthropogenic fragments of Brazilian Atlantic Forest. Annals of the Brazilian Academy of Sciences, 76: 429-434.
AnJos, L. DOS. 2006. Bird species sensitivity in a fragmented landscape of the Atlantic Forest in Southern Brazil. Biotropica, 38: 229-234.

AnJos, L. DOs and Boçon, R. 1999. Bird communities in natural forest patches in Southern Brazil. Wilson Bulletin, 111: 397-414.

Anjos, L. Dos, Holt, R. D. and Scott, R. 2010a. Position in the distributional range and sensitivity to forest fragmentation in birds: a case history from the Atlantic forest, Brazil. Bird Conservation International, 20: 392-399.

Anjos, L. Dos, Volpato, G. H., Mendonça, L. B., SERAFini, P. P., LoPEs, E. V., Boçon, R., Silva, E. S. and Bisheimer, M. V. 2010b. Técnicas de levantamento quantitativo de aves em ambiente florestal: uma análise comparativa baseada em dados empíricos. In, Von Matter, S., Straube, F. C., Accordi, I., Piacentini, V. and Cândido-Jr., J. F. (Orgs): Ornitologia e Conservação: Ciência Aplicada, Técnicas de Pesquisa e Levantamento, pp. 63-76. Editora Technical Books, Rio de Janeiro.

Anjos, L. Dos, Collins, C. D., Holt, R. D., Volpato, G. H., Mendonça, L. B., Lopes, E. V., Boçon, R., Bisheimer, M. V., SERAfini, P. P. and Carvalho, J. 2011. Bird species abundance occupancy patterns and sensitivity to forest fragmentation: Implications for conservation in the Brazilian Atlantic forest. Biological Conservation, 144: 2213-2222.

Antongiovanni, M. and Metzger, J. P. 2005. Influence of matrix habitats on the occurrence of insectivorous bird species in Amazonian forest fragments. Biological Conservation, 122: 441-451.

Benjamini, Y. and Hochberg, Y. 1995. Controlling the False Discovery Rate: A Practical and Powerful Approach to Multiple Testing. Journal of the Royal Statistical Society. Series B, 57: 289-300.

Bibby, C., Burguess, N. D. and Hill, D. A. 1993. Bird census techniques. British Trust for Ornithology and the Royal Society for the Protection of Birds. Academic Press. London.

Blondel, J., Ferry, C. and Frochot, B. 1970. La méthode des indices ponctuels d'abondance (I.P.A.) ou des releves d'avifaune par "stations d'écoute". Alauda, 38: 55-71. 
Campos, J. B. and SouzA, M. C. 1997. Vegetação. In, Vazzoler, A. E. A. M., Agostinho, A. A. and Hahn, N. S. (Eds): A planície de inundação do alto rio Paraná: aspectos físicos, biológicos e socioeconômicos, pp. 331-342. EDUEM, Maringá, Brasil.

Christiansen, M. B. and PitTer, E. 1997. Species loss in a forest bird community near Lagoa Santa in Southeastern Brazil. Biological Conservation, 80: 23-32.

Del Hoyo, J., Elliot, A., Sargatal, J. and Christie, D. A. (Eds). 1992-2011. Handbook of the Birds of the World. Vols 1-16. Lynx Edicions. Barcelona.

Dunning, J. B. 2008. CRC Handbook of avian body masses, 2nd ed. CRC Press. Printed in the U.S.A.

FARIA, D., PACIÊNCIA, M. L. B., LAPs, R. R., Baumgarten, J. and Cetra, M. 2006. Bat and bird assemblages from forests and shade cacao plantations in two contrasting landscapes in the Atlantic Forest of southern Bahia, Brazil. Biodiversity and Conservation, 15: 587-612.

FARIA, D., PACIÊNCIA, M. L. B., DiXo, M., LAPS, R. R. and BAUMGARTEN, J. 2007. Ferns, frogs, lizards, birds and bats in forest fragments and shade cacao plantations in two contrasting landscapes in the Atlantic forest, Brazil. Biodiversity and Conservation, 16: 2335-2357.

Feeley, K. J. and Terborgh, J. W. 2008. Direct vs. indirect effects of habitat reduction on the loss of avian species from tropical forest fragments. Animal Conservation, 11: 353-360.

Ferraz, G., Russell, G. J., Stouffer, P. C., Bierregaard Jr., R. O., Pimm, S. L. and Lovejoy, T. E. 2003. Rates of species loss from Amazonian forest fragments. Proceedings of the National Academy of Sciences, USA, 100: 14069-14073.

Fowler, J. and CoHEN, L. 1986. Statistics for ornithologists. British Trust for Ornithology. Thetford.

Gascon, C., Lovejoy, T. E., BierregaArd JR., R. O., Malcolm, J. R., Stouffer, P. C., VasconCelos, H. L., Laurance, W. F., Zimmerman, B., Tocher, M. and Borges, S. 1999. Matrix habitat and species richness in tropical forest remnants Biological Conservation, 91: 223229.
Gustafson, E. J. and PARKer, G. R. 1992. Relationships between landcover proportion and indices of landscape spatial pattern. Landscape Ecolology, 7: 101-110.

Gustafson, E. J. and PARKeR, G. R. 1994. Using an index of habitat patch proximity for landscape design. Landscape and Urban Planning, 29:117-130.

LAURANCE, W. F. 2010. Understanding habitat fragmentation in the real world. In, Losos, J. B. and Ricklefs, R. E. (Eds): The Theory of Island Biogeography Revisited, pp. 214-236. Princeton University Press. New Jersey.

Laurance, W. F., Lovejoy, T. E., Vasconcelos, H. L., Bruna, E. M., DidHAM, R. K., STOUfFer, P. C., Gascon, C., Bierregaard JR., R. O., Laurance, S. G. and Sampaio, E. 2002. Ecosystem decay of Amazonian forest fragments, a 22-year investigation. Conservation Biology, 16: 605-618.

Laurance, W. F. and Vasconcelos, H. L. 2009. Consequências ecológicas da fragmentação florestal na Amazônia. Oecologia Brasiliensis, 13: 434-451.

LECK, C. F. 1979. Avian extinctions in an isolated tropical wet-forest preserve, Ecuador. Auk, 96: 343-352.

Lees, A. C. and Peres, C. A. 2006. Rapid avifaunal collapse along the Amazonian deforestation frontier. Biological Conservation, 133: 198-211.

Lees, A. C. and Peres, C. A. 2010. Habitat and Life History Determinants of Antbird Occurrence in Variable-Sized Amazonian Forest Fragments. Biotropica, 42: 614-621.

MAACK, R. 1981. Geografia física do estado do Paraná. 2nd ed. Curitiba: Secretaria da Cultura e do Esporte do governo do estado do Paraná. Editora José Olympio. Rio de Janeiro.

Marini, M. Â. and DurÃEs, R. 2001. Annual patterns of molt e reproductive activity of Passerines in South-central Brazil. Condor, 103: 767-775.

Martensen, A. C., Pimentel, R. G. and Metzger, J. P. 2008. Relative effects of fragment size and connectivity on bird community in the Atlantic Rain Forest: implications for conservation. Biological Conservation, 141: 21842192. 
McGarigal, K., Cushman, S. A. and Ene, E. 2012. FRAGSTATS v4: Spatial pattern analysis program for categorical and continuous maps. Computer software program produced by the authors at the University of Massachusetts, Amherst. Available from http://www.umass. edu/landeco/research/fragstats/fragstats.html (accessed June 2014).

PArker III, T. A., Stotz, D. F. and FitzPatrick, J. W. 1996. Ecological and distribution databases. In, Stotz, D. F., Fitzpatrick, W. J., Parker III, T. A. and Moskovits, D. K. (Eds.): Neotropical birds: ecology and conservation, $\mathrm{pp}$. 118-436. University of Chicago press. Chicago.

Piratelli, A., Siqueira, M. A. C. and MarcondesMachado, L. O. 2000. Reprodução e muda de penas em aves de sub-bosque na região leste de Mato do Sul. Ararajuba, 8: 99-107.

R Development Core Team. 2008. R: A language and environment for statistical computing. $\mathrm{R}$ Foundation for Statistical Computing,Vienna, Austria. ISBN 3-900051-07-0, http://www.Rproject.org.

Restrepo, C., Renjifo, L. M. and Marples, P. 1997. Frugivorous birds in fragmented Neotropical montane forests: landscape pattern and body mass distribution. In, Laurance, W. F. and Bierregaard Jr., R. O. (Eds): Tropical Forest Remnants: Ecology, Management, and Conservation of Fragmented Communities, pp. 171189. University of Chicago Press. Chicago.

Ribon, R., Simon, J. E. and Mattos, G. T. 2003. Bird extinctions in Atlantic Forest fragments of the Viçosa Region, Southeastern Brazil. Conservation Biology, 17: 1827-1839.

SodHI, N. S., Liow, L. H. and BazZAZ, F. A. 2004. Avian extinctions from tropical and subtropical forests. Annual Review of Ecology, Evolution and Systematics, 35: 323-345.

Stouffer, P. C. and BierregaArd Jr., R. O. 1995. Use of Amazonian forest fragments by understory insectivorous birds. Ecology, 76: 2429-2445.

Stouffer, P. C., Bierregahrd Jr., R. O., Strong, C. and Lovejoy, T. E. 2006. Long- term landscape change and bird abundance in Amazonian rain forest fragments. Conservation Biology, 20: 1212-1223.

Uezu, A., Metzger, J. P. and Vielliard, J. M. E. 2005. Effects of structural and functional connectivity and patch size on the abundance of seven Atlantic Forest bird species. Biological conservation, 123: 507-519.

Uezu, A., Beyer, D. D. and Metzger, J. P. 2008. Can agroforest woodlots work as stepping stones for birds in the Atlantic Forest region? Biodiversity and Conservation, 17: 1907-1922. WILlIS, E. O. 1979. The composition on avian communities in remanescent woodlots in Southern Brazil. Papeis Avulsos de Zoologia, 33: 1-25.

YABE, R. DE S. and Marques, E. J. 2001. Deslocamento de aves entre capões no Pantanal mato-grossense e sua relação com a dieta. In, Albuquerque, J. L. B., Cândido Jr., J. F. and Straube, F. C. (Eds): Ornitologia e conservação: da ciência às estratégias, pp. 103-124. Editora UNISUL. Tubarão.

\section{SupPlementary EleCtronic Material}

Additional supporting information may be found in the on-line version of this article. See volume 63(2) on www.ardeola.org.

Appendix 1. Number of contacts and sensitivity to forest fragmentation (SE) category (Yes or No) of each bird species recorded in the present study in large (LA) and small (SM) forest remnants on the eastern and western riverbanks of the Paraná River.

Received: 21 September 2015 Acepted: 11 May 2015

Editors: Gustavo Andres Zurita and César Cestari 